\title{
Organic contamination versus mineral properties: competing selective forces shaping bacterial community assembly in aquifer sediments
}

\author{
Michael Grösbacher ${ }^{1}$, Carolin Spicher ${ }^{1}$, Anne Bayer ${ }^{2}$, Martin Obst $^{3}$, Clemens Karwautz $^{1}$, \\ Giovanni Pilloni ${ }^{1,6}$, Martin Wachsmann ${ }^{4}$, Hagen Scherb ${ }^{5}$, Christian Griebler ${ }^{1, *}$ \\ ${ }^{1}$ Institute of Groundwater Ecology, Helmholtz Zentrum München, 85764 Neuherberg, Germany \\ ${ }^{2}$ Bayerisches Landesamt für Umwelt, 82407 Wielenbach, Germany \\ ${ }^{3}$ Center for Applied Geosciences, Institute for Geosciences, Eberhard Karls Universität Tübingen, 72074 Tübingen, Germany \\ ${ }^{4}$ Ludwig-Maximilians-Universität München, Department of Earth and Environmental Sciences, Section for Mineralogy, \\ Petrology and Geochemistry, 80333 München, Germany \\ ${ }^{5}$ Institute of Computational Biology, Helmholtz Zentrum München, 85764 Neuherberg, Germany \\ ${ }^{6}$ Present address: ExxonMobil Research and Engineering, Corporate Strategic Research, Annandale, NJ 08801, USA
}

\begin{abstract}
Multiple factors have been shown to influence the assembly of sediment microbial communities. We hypothesized that in an organically polluted aquifer, the degree of contamination controls bacterial distribution patterns, superimposing other selective forces such as sediment and mineral properties. Groundwater and sediment samples were analyzed from distinct zones of a petroleum hydrocarbon contaminated sandy aquifer that correspond to different degrees of contamination: Zone 1, with a high concentration of dissolved contaminants (benzene, toluene, ethylbenzene, and xylenes); Zone 2, with high concentrations of sediment-bound polycyclic aromatic hydrocarbons (PAHs); and Zone 3, with only minor PAH contamination. Sediment analysis concentrated on 2 mineral fractions differing in many sediment properties, i.e. translucent quartz (TQ) and mica. Sediment bacterial communities were analyzed by DNA fingerprinting (terminal restriction fragment length polymorphism) and total cell counts. While Zone 1 exhibited highly similar communities on TQ and mica, the selective sorption of PAHs to mica revealed sediment bacterial communities with hardly any taxonomic units shared in Zone 2. Typical selective forces active in sediments of oligotrophic habitats, such as sediment mineral content and surface roughness, only gained influence in Zone 3. Similarly, the least contamination revealed the most pronounced differences in Shannon diversity, evenness, and total cell counts between the mineral fractions tested, with mica characterized by highest biomass and bacterial diversity. The role of contamination as a selective force is also underlined by the zone-specific dominance of key microbes involved in petroleum hydrocarbon degradation. Our results demonstrate that typical selective forces shaping aquifer sediment microbial communities are outcompeted by organic contamination.
\end{abstract}

*Corresponding author: griebler@helmholtz-muenchen.de

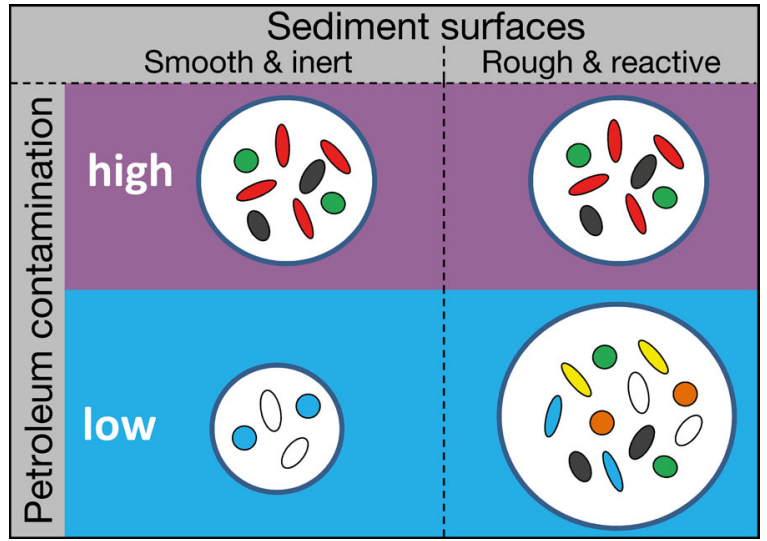

Microbial community assemblages and cell densities are determined by organic contamination rather than mineral properties.

Image: Christian Griebler \& Clemens Karwautz

KEY WORDS: Aquifer microbiology · Groundwater · Petroleum hydrocarbons - Sediment community assembly $\cdot$ Selective forces $\cdot$ Quartz $\cdot$ Mica

\section{INTRODUCTION}

The majority of prokaryotic cells in aquifers are found attached to the sediment surface, while only a minor portion (0.01 to $10 \%$ ) are freely floating in the pore water (Alfreider et al. 1997, Geesey 2001, Griebler et al. 2002, Zhou et al. 2012). Numerous abiotic and biotic factors drive the colonization of sediment surfaces and the

(C) The authors 2016. Open Access under Creative Commons by Attribution Licence. Use, distribution and reproduction are unrestricted. Authors and original publication must be credited. 
subsequent composition of communities as well as the distribution of cells between the pore water and the solid phase (Reardon et al. 2004, Fazi et al. 2008, Kanzog \& Ramette 2009, Augspurger et al. 2010, Flynn et al. 2013, Rizoulis et al. 2013). In habitats poor in nutrients and/or organic carbon, sediment surfaces have frequently been suggested to be attractive habitats for microbes since they are offering access to limiting elements contained in the minerals (Banfield \& Hamers 1997, Bennett et al. 2000, 2001, Rogers \& Bennett 2004, Boyd et al. 2007, Mauck \& Roberts 2007, Carson et al. 2009, Gadd 2010). Indeed, surfaces are sites of adsorption of organic molecules and thus may provide a reservoir of organic matter under limiting conditions (Bakker et al. 2003). Besides the mineral composition and accumulation of organic carbon, various other properties of sediments may play an important role in bacterial colonization, with, for example, grain size and shape influencing microbial community composition (Nickels et al. 1981, Llobet-Brossa et al. 1998, Edwards \& Rutenberg 2001, Köster et al. 2005). Rough surfaces providing a higher surface area encourage bacterial settlement more strongly than smooth surfaces (Dubois et al. 2010). In this context, a point of discussion is that cells colonizing fissures and depressions at surfaces are protected from direct shear forces as well as from direct protozoan grazing (Kölbel-Boelke \& Hirsch 1989). The same is argued for the embedment of individual cells in biofilms. Hydrodynamic conditions are thus another key factor influencing the colonization of surfaces in water (Augspurger et al. 2010).

Suspended and attached prokaryotic communities in aquifers differ not only in terms of cell numbers but in other ways as well. Early research demonstrated that attached populations may exhibit distinct cell morphology (Hirsch et al. 1992) and physiology (Kölbel-Boelke \& Hirsch 1989, Hirsch 1992, Watnick \& Kolter 2000). More recently, it has been confirmed that suspended and attached prokaryotic communities most often show striking differences also in community composition (Reardon et al. 2004, Flynn et al. 2008, 2013, Griebler \& Lueders 2009, Anneser et al. 2010, Rizoulis et al. 2013, Hug et al. 2015). The factors responsible include those mentioned above as well as additional ones such as the chemical composition of the groundwater, substrate, and electron acceptor availability, the redox conditions and, explicitly, the impact of contaminants (Griebler \& Lueders 2009, Rizoulis et al. 2013). All of these factors act as selective forces on the prokaryotic communities dwelling on the sediment surfaces. To date, only a few studies have taken a comparative look at the importance of individual driving forces governing the characteristics of sediment prokaryotic communities.

Here, we tested the working hypothesis that high concentrations of organic pollutants such as petroleum hydrocarbons act as a dominant selective force on the prokaryotic communities attached to sediment surfaces, being toxic for some of their members while providing others with a source of carbon and energy (Heider 2007, Foght 2008). We propose that at high contaminant concentrations, other selective factors such as sediment and mineral properties as well as physical-chemical conditions are of comparatively minor influence but become more relevant once contaminant concentrations become low. We analyzed sediments from an organically polluted aquifer exposed to different concentrations of petroleum hydrocarbons. Samples were collected from Zone 1, with high concentrations of contaminants, i.e. monoaromatic (benzene, toluene, ethylbenzene, and xylenes [BTEX]) and polycyclic aromatic hydrocarbons (PAHs), both dissolved in the groundwater and adsorbed to the sediment matrix; Zone 2, dominated by adsorbed contaminants but poor in dissolved contaminants; and Zone 3, with only a low PAH background adsorbed to the sediment. Detailed investigations involved qualitative and quantitative analyses of the bacterial communities and concentrated exemplarily on 2 very different types of minerals contained in the natural Quaternary sandy sediment, namely particles of translucent quartz (TQ) with smooth surfaces and rough black mica grains.

\section{MATERIALS AND METHODS}

\section{Field site and sampling of groundwater and sediments}

Groundwater and sediments were collected at a former gasworks site in Düsseldorf-Flingern, Germany. The Quaternary shallow sandy aquifer, contaminated over several decades with tar oil and residues of gasification of coal, today, after individual remediation activities, harbors a vertically thin plume of aromatic hydrocarbons dissolved in groundwater consisting mainly of BTEX and naphthalene. Additionally, PAHs are locally distinct and found adsorbed to the sediment matrix (Fig. 1) (Anneser et al. 2008, 2010).

Water samples for the analysis of dissolved organic contaminants and water chemistry were col- 




Fig. 1. Vertical distribution of (a) monoaromatic hydrocarbons (benzene, toluene, ethylbenzene, and xylenes [BTEX]) and naphthalene in groundwater (gw), (b) sum of USEPA polycyclic aromatic hydrocarbons (EPA-PAHs) sorbed to the sediment (sed) matrix, and (c) total number of prokaryotic cells attached to the sediments at counts in natural (mixed) sediment samples obtained after reprocessing samples from the 3 selected depths (6.80 to $6.85,7.20$ to 7.25 , and 10.65 to $10.70 \mathrm{~m}$ below land surface [bls]); for further explanation, refer to text. Values are means \pm SD the test site in Düsseldorf-Flingern, Germany. Stars depict values of total cell

\section{Groundwater analyses}

Groundwater was withdrawn simultaneously from the 3 sampling depths, collected in $100 \mathrm{ml}$ glass bottles, and processed immediately for measuring electric conductivity, $\mathrm{pH}$, and redox potential $\left(E_{H}\right)$ as well as for the analysis of dissolved iron and sulfide species, which were quantified on-site. Samples for the measurement of major anions and cations were cooled and analyzed back in the lab via ion chromatography (Dionex DC-100).

Groundwater samples dedicated to the analysis of dissolved monoand polycyclic aromatic hydrocarbons were immediately split to glass vials of different volumes and treated with $\mathrm{NaOH}(0.1 \mathrm{M}$ final concentration) to stop biological activity before being closed tightly. Later, BTEX concentrations were measured via GC-MS by headspace analysis. The less volatile PAHs were extracted from $13 \mathrm{ml}$ groundwater samples by adding $500 \mu \mathrm{l}$ of cyclohexane and shaking intensively for $60 \mathrm{~min}$. Contamilected using a special high-resolution multi-level well. Fresh sediment samples were obtained by drilling. Sediment cores were subsampled under a continuous stream of argon gas. A detailed description of groundwater and sediment sampling is described in Anneser et al. (2008). The samples processed for this study originated from a survey in June 2009 and represent 3 zones of different contamination. Zone 1 was located at the time of sampling within the plume of dissolved contaminants (BTEX and naphthalene) at a depth between 6.80 and $6.85 \mathrm{~m}$ below land surface (bls) (Fig. 1, Table 1). Zone 2 (at 7.20 to $7.25 \mathrm{~m}$ bls) represents an area characterized by low concentrations of BTEX but high concentrations of PAHs adsorbed to the sediment (Fig. 1, Table 1). Zone 3, at 10.65 to $10.70 \mathrm{~m}$ bls, was located beneath the highly contaminated area, with BTEX compounds below detection and low background concentrations of PAHs (Fig. 1, Table 1). Further biogeochemical characteristics of groundwater from the individual depths are summarized in Table 1. nant concentrations in the cyclohexane phase were then determined by GC-MS via liquid injection. Detailed protocols are given in Anneser et al. (2008, 2010).

\section{Analysis of sediment samples}

Sediments from 3 depths were immediately processed for different subsequent analyses. Samples for community profiling and later mineralogical characterization were shock frozen on dry ice, while samples for cell counts were fixed with glutardialdehyde (2.5\% final conc.). Concentrations of contaminants were determined from sediments after extraction (see section below).

\section{Analysis of sediment contaminant content}

PAHs adsorbed to the sediment were extracted with acetone at the presence of an internal standard 
Table 1. Selected biogeochemical features of groundwater and sediment at 3 selected zones of varying contamination in a tar oil contaminated aquifer in Düsseldorf-Flingern, Germany. Depths of sediment origin are not absolute but may vary $\pm 2.5 \mathrm{~cm}$. Thus, groundwater features in the case of Zones 1 and 2 represent mean values of 2 depths and in the case of Zone 3 refer to values obtained for a depth of $11.20 \mathrm{~m}$ below land surface. $\mathrm{E}_{\mathrm{H}}$ : redox potential; EC: electric conductivity; Fe(II): ferrous iron; DOC: dissolved organic carbon; BTEX: benzene, toluene, ethylbenzene, and xylenes; EPA-PAHs: USEPA polycyclic aromatic hydrocarbons; nd: not detected

\begin{tabular}{|c|c|c|c|}
\hline Parameter & $\begin{array}{l}\text { Zone } 1 \\
5.80-6.85 \mathrm{~m}\end{array}$ & $\begin{array}{c}\text { Zone } 2 \\
7.20-7.25 \mathrm{~m}\end{array}$ & $\begin{array}{c}\text { Zone } 3 \\
10.65-10.70 \mathrm{~m}\end{array}$ \\
\hline \multicolumn{4}{|l|}{ Groundwater } \\
\hline Cells $\mathrm{ml}^{-1} \times 10^{6}$ & 1.14 & 3.61 & 0.5 \\
\hline $\mathrm{E}_{\mathrm{H}}(\mathrm{mV})$ & -80 & -45 & -44 \\
\hline $\mathrm{EC}\left(\mu \mathrm{S} \mathrm{cm} \mathrm{cm}^{-1}\right)$ & 1160 & 1240 & 1170 \\
\hline Alkalinity (mEq l$~^{-1}$ ) & 9.5 & 8.5 & 8.4 \\
\hline Nitrate $\left(\mathrm{mg} \mathrm{l}^{-1}\right)$ & 0.04 & nd & nd \\
\hline Sulfate $\left(\mathrm{mg} \mathrm{l}^{-1}\right)$ & 171 & 240 & 288 \\
\hline Sulfide $\left(\mathrm{mg} \mathrm{l}^{-1}\right)$ & 5.1 & 0.2 & nd \\
\hline $\mathrm{Fe}(\mathrm{II})\left(\mathrm{mg} \mathrm{l}^{-1}\right)$ & 1.1 & 0.2 & 3.4 \\
\hline $\mathrm{DOC}\left(\mathrm{mg} \mathrm{l}^{-1}\right)$ & 8.3 & 3.85 & 2.5 \\
\hline Benzene $\left(\mathrm{mg} \mathrm{l}^{-1}\right)$ & 0.04 & 0.01 & nd \\
\hline Toluene $\left(\mathrm{mg} \mathrm{l}^{-1}\right)$ & 4 & 0.08 & nd \\
\hline Ethylbenzene $\left(\mathrm{mg} \mathrm{l}^{-1}\right)$ & 0.3 & 0.008 & nd \\
\hline m/p-xylene $\left(\mathrm{mg} \mathrm{l}^{-1}\right)$ & 1.1 & 0.003 & nd \\
\hline$o$-xylene $\left(\mathrm{mg} \mathrm{l}^{-1}\right)$ & 0.4 & 0.003 & nd \\
\hline BTEX total $\left(\mathrm{mg} \mathrm{l}^{-1}\right)$ & 6.3 & 0.1 & nd \\
\hline Dibenzofuran (mg l$\left.{ }^{-1}\right)$ & 0.5 & 0.2 & nd \\
\hline Naphthalene $\left(\mathrm{mg} \mathrm{l}^{-1}\right)$ & 1.9 & 0.008 & nd \\
\hline Indane $\left(\mathrm{mg} \mathrm{l}^{-1}\right)$ & 0.2 & nd & nd \\
\hline Indene $\left(\mathrm{mg} \mathrm{l}^{-1}\right)$ & 0.04 & nd & nd \\
\hline Fluorene $\left(\mathrm{mg} \mathrm{l}^{-1}\right)$ & 0.03 & nd & nd \\
\hline Acenaphthene $\left(\mathrm{mg} \mathrm{l}^{-1}\right)$ & 0.9 & 0.6 & 0.07 \\
\hline EPA-PAHs $\left(\mathrm{mg} \mathrm{l}^{-1}\right)$ & 4.8 & 0.5 & 0.05 \\
\hline \multicolumn{4}{|l|}{ Sediment } \\
\hline $\begin{array}{l}\text { Cells g }{ }^{-1} \text { sediment wet } \\
\text { wt } \times 10^{7}\end{array}$ & 6.9 & $1.6-2.2$ & 0.21 \\
\hline Naphthalene $\left(\mathrm{mg} \mathrm{kg}^{-1}\right)$ & 11.7 & 18.7 & 0.03 \\
\hline Acenaphthene $\left(\mathrm{mg} \mathrm{kg}^{-1}\right)$ & 1) 3.3 & 15.3 & nd \\
\hline Fluorene $\left(\mathrm{mg} \mathrm{kg}^{-1}\right)$ & 0.6 & 20.6 & 1.7 \\
\hline EPA-PAHs (mg kg$\left.{ }^{-1}\right)$ & 15.6 & 54.6 & 1.7 \\
\hline
\end{tabular}

mixture containing deuterated acenaphthene, chrysene, perylene, and phenanthrene species (Internal Standards Mix 25, Dr. Ehrenstorfer). Aromatic hydrocarbons were determined with GC-MS, applying the settings as described in Anneser et al. (2010).

\section{Sorting of sediment mineral fractions}

The samples from the 3 selected depths mainly consisted of medium sand with a diameter of 0.2 to $0.63 \mathrm{~mm}$. For sorting, frozen (dedicated to DNA extraction and mineral characterization) and fixed sediments (dedicated to total cell counting) were transferred to a sterile Petri dish of $6 \mathrm{~cm}$ diameter containing sterile phosphate-buffered saline (PBS) buffer $(10 \mathrm{mM})$. Sorting was carried out using a sterile spatula and forceps under a stereo microscope, with the Petri dish being placed on an aluminum cooling block. For the following experiments, 4 fractions of sediment were considered: (1) natural mixed sediments; (2) TQ grains; (3) mica grains; and (4) the remaining sediment (sediment fraction after the majority of $\mathrm{TQ}$ and mica was removed by sorting; this sediment fraction was then mainly composed of coated quartz grains and a small content of silt and clay) (see Fig. S1 in the Supplement at www.int-res.com/articles/suppl/a076 p243_supp.pdf). After sorting, the fractions were transferred into separate $1.5 \mathrm{ml}$ Eppendorf tubes and stored either in a solution of glutardialdehyde ( $2 \%$ final conc.) for total cell counting or at $-22^{\circ} \mathrm{C}$ for community analysis and mineral characterization.

Sediment surface area and roughness

TQ and mica particles were chosen because of their strongly differing properties. Quartz grains were characterized by flat, smooth surfaces, while the surfaces of mica particles were comparably rough (Fig. S1). The surface area of both mica and quartz particles has been calculated using the equation for the external specific surface area as described in Dubois et al. (2010). The roughness factor was 34 for quartz and 126 for mica, as stated in Suarez \& Wood (1998).

\section{Sediment elemental composition}

After drying of sediment particles, the elemental composition of individual grains was determined by scanning electron microscopy (SEM) in combination with energy-dispersive X-ray spectrometry (EDX) using a Leo 1450 VP SEM equipped with an Oxford INCA Energy 200 Premium Si (Li) super atmospheric thin window detector. An acceleration voltage of $20 \mathrm{kV}$ and a probe current of $221 \mathrm{pA}$ were used. X-ray spectra for quantification were acquired on flat parts in the center of the grains to avoid artifacts from sample topography. At least 10 spectra of individual particles were measured for each sample type. Elemental quantification was done using the Oxford INCA software package. 


\section{Cell detachment and total cell counting}

To detach the cells, 0.1 to $0.5 \mathrm{~g}$ of the sorted sediment was transferred into a $2 \mathrm{ml}$ Eppendorf tube. If less than $0.5 \mathrm{~g}$ of sediment was chosen or available, sterile quartz grains were added to a final weight of $0.5 \mathrm{~g}$. Subsequently, $1.5 \mathrm{ml}$ of $10 \mathrm{mM}$ PBS was added to each sample before they were placed on a swing mill (Retsch) and shaken for $3 \mathrm{~min}$ at $20 \mathrm{~Hz}$ (Bayer et al. 2016). After $5 \mathrm{~min}$ of sedimentation, the supernatant (ca. $1.5 \mathrm{ml}$ ) was carefully transferred into ultra-centrifuge tubes on top of $5 \mathrm{ml}$ cold Nycodenz solution $\left(1.3 \mathrm{~g} \mathrm{ml}^{-1}\right)$. This mechanical dislodgement step was repeated so that the total volume in the ultra-centrifuge tubes finally equaled $8 \mathrm{ml}$. Samples were centrifuged at $11000 \mathrm{rpm}(15500 \times \mathrm{g})$ and $4^{\circ} \mathrm{C}$ for $1 \mathrm{~h}$. Subsequently, the top $6.5 \mathrm{ml}$ of each tube containing the cells but no additional larger inorganic particles was transferred to test tubes containing $5 \mathrm{ml}$ sterile filtered $10 \mathrm{mM}$ PBS and $15 \mu \mathrm{l}$ of the nucleic acid stain Sybr-Green I (1000×, Molecular Probes). After brief vortexing and incubation for $15 \mathrm{~min}$ at room temperature in darkness, samples were filtered through a $0.2 \mu \mathrm{m}$ black polycarbonate filter $(\varnothing 25 \mathrm{~mm}$, Whatman), embedded in anti-fading reagents (50\% glycerol in $20 \mathrm{mM}$ phosphate buffer and $0.1 \% p$ phenylenediamine), and placed on a microscope slide. A minimum of 500 cells per sample was counted under the epifluorescence microscope (Zeiss Axioscope) at $1000 \times$ magnification.

\section{DNA extraction and community fingerprinting}

DNA extraction from aquifer sediment (both sorted fractions and natural sediment) and terminal restriction fragment length polymorphism (T-RFLP) analysis were performed as described in Winderl et al. (2008) and Pilloni et al. (2011). Data evaluation was performed as reported elsewhere (Pilloni et al. 2012, Larentis et al. 2013). Data from 454 pyrosequencing as conducted in previous studies at this site (Winderl et al. 2008, Anneser et al. 2010, Pilloni et al. 2012, Larentis et al. 2013) were used to assign the most common terminal restriction fragments (T-RFs) to specific taxonomic groups. Briefly, forward and reverse quality-trimmed pyrosequencing reads were assembled into short contigs (up to $\sim 500 \mathrm{bp}$ ) using the software Seqman II (DNAStar). Contigs were then aligned into an ARB (Ludwig et al. 2004) database (version SSURef-95, July 2008), and T-RFs of amplicon contigs were predicted using arb_edit4. Deviations between predicted and measured T-RFs were eventually handled by referring to our previously analyzed cloned amplicons from the same contaminated site (Winderl et al. 2008). For community fingerprinting of the TQ and mica fractions, we were unfortunately not able to analyze biological replicates but only technical replicates (duplicates and occasionally triplicates) because of the limited material available after sorting. Earlier studies on sediments from the same sites showed a low variability within biological replicates and a high reproducibility of technical replicates with our T-RFLP protocol (Pilloni et al. 2012). Moreover, key degrader populations identified match well with the findings from earlier studies (Winderl et al. 2008, Anneser et al. 2010, Larentis et al. 2013).

\section{Data preparation and statistical analysis}

An unconstrained correspondence analysis was used to analyze the community composition of the 6 different samples (mica and quartz in the 3 different zones). The dominant $\mathrm{T}$-RFs with a relative abundance higher than $5 \%$ in at least one of the samples were picked, resulting in 17 T-RFs. In this analysis, distances between objects (samples) are preserved; therefore, distances between samples represent their similarity. Environmental vectors were fitted onto this ordination using the envfit function provided in the vegan package (Oksanen et al. 2013) implemented in the open-source platform R (version 3.1.0). Individual contaminants were summarized into the categories BTEX (benzene, toluene, ethylbenzene, $m$-/ $p$-xylene, and $o$-xylene), PAHs in water (naphthalene, dibenzofuran, fluorine, and acenaphthene), and PAHs adsorbed to the sediment (naphthalene, acenaphthene, and fluorene). The significance of the fitted vectors was assessed using 720 permutations, setting the alpha level to 0.05 .

A principal component analysis (PCA) was used to elucidate the main environmental variables separating the different samples. The variables (as described above) were standardized to $z$-scores.

Venn diagrams were drawn to show overlapping and unique T-RFs. Information on the abundance was transformed to presence-absence data, and TRFs of the 3 different zones were compared regarding their appearance on one of the 4 different sediment fractions (mica, TQ, remaining sediment, and natural mixed sediment).

Differences between individual samples and treatments were evaluated using a rank sum test (MannWhitney $U$-test). 


\section{RESULTS}

\section{Distribution of contaminants and overall physicochemical conditions}

The environmental conditions in the 3 zones of the organically contaminated aquifer investigated were significantly different in many respects. Zone 1 was characterized by comparably high concentrations of BTEX and PAHs dissolved in groundwater, with concentrations of 6.3 and $4.8 \mathrm{mg} \mathrm{l}^{-1}$, respectively (Table 1, Fig. 1). Values obtained for BTEX and PAHs match well with the $8.3 \mathrm{mg} \mathrm{l}^{-1}$ of dissolved organic carbon (DOC) when considering that part of the very volatile contaminants get lost during DOC measurement. PAHs adsorbed to the sediment accounted for $15.6 \mathrm{mg}$ $\mathrm{kg}^{-1}$ sediment (wet wt), with $75 \%$ represented by naphthalene (Table 1). Zone 1 was highly reduced $\left(E_{\mathrm{H}}=-80 \mathrm{mV}\right)$ and exhibited strong evidence for active sulfate and iron reduction, indicated by the concentrations of dissolved sulfide (5.1 $\mathrm{mg} \mathrm{l}^{-1}$ ) and ferrous iron (1.1 $\mathrm{mg} \mathrm{l}^{-1}$ ) (Table 1).

Zone 2 was characterized by considerably lower concentrations of dissolved contaminants, with only $0.1 \mathrm{mg} \mathrm{l}^{-1}$ of BTEX and $1 \mathrm{mg} \mathrm{l}^{-1}$ of PAHs. However, this zone contained $54.6 \mathrm{mg} \mathrm{kg}^{-1}$ sediment (wet wt) of PAHs adsorbed to the matrix, almost equally composed of naphthalene, acenaphthene, and fluorene (Table 1, Fig. 1). Concentrations of dissolved sulfide and ferrous iron were both in the range of $0.2 \mathrm{mg} \mathrm{l}^{-1}$, and the redox potential increased to $E_{\mathrm{H}}=-45 \mathrm{mV}$ when compared to Zone 1 (Table 1).

Zone 3 was located 3.5 to $4 \mathrm{~m}$ vertically distant from Zones 1 and 2 outside the main area of contamination. Still, a minor PAH background of $1.7 \mathrm{mg} \mathrm{kg}^{-1}$ sediment (wet wt) (mainly fluorene) adsorbed to the sediment was present. Monoaromatic hydrocarbons were below the detection limit, and PAHs dissolved in groundwater accounted for less than $0.1 \mathrm{mg} \mathrm{l}^{-1}$ (Table 1). While no sulfide was found in dissolved form, there was evidence for active iron reduction from ferrous iron concentrations of $3.4 \mathrm{mg} \mathrm{l}^{-1}$. The redox potential was similar to the one measured in Zone 2 (Table 1).

\section{Mineral composition of sediments}

Mineralogical examination of the selected sediments revealed a high content of quartz, with 10 to $14 \%$ of TQ grains and 74 to $77 \%$ of quartz particles coated with reddish and greenish precipitate; 12 to $15 \%$ of the sediments were clay and silt par-
Table 2. Mineral composition of sediment samples from 3 different depths

\begin{tabular}{cccccc}
$\begin{array}{c}\text { Zone } \\
\text { Depth } \\
(\mathrm{m})\end{array}$ & $\begin{array}{c}\text { Translucent } \\
\text { quartz (\%) }\end{array}$ & $\begin{array}{c}\text { Mica } \\
(\%)\end{array}$ & $\begin{array}{c}\text { Clay } \\
\text { slate }(\%)\end{array}$ & $\begin{array}{c}\text { Laminated } \\
\text { quartz (\%) }\end{array}$ \\
\hline 1 & $6.80-6.85$ & 10.4 & 1 & 12 & 76.6 \\
2 & $7.20-7.25$ & 14.1 & 0.1 & 12 & 73.9 \\
3 & $10.65-10.70$ & 11.1 & 0.1 & 15 & 74
\end{tabular}
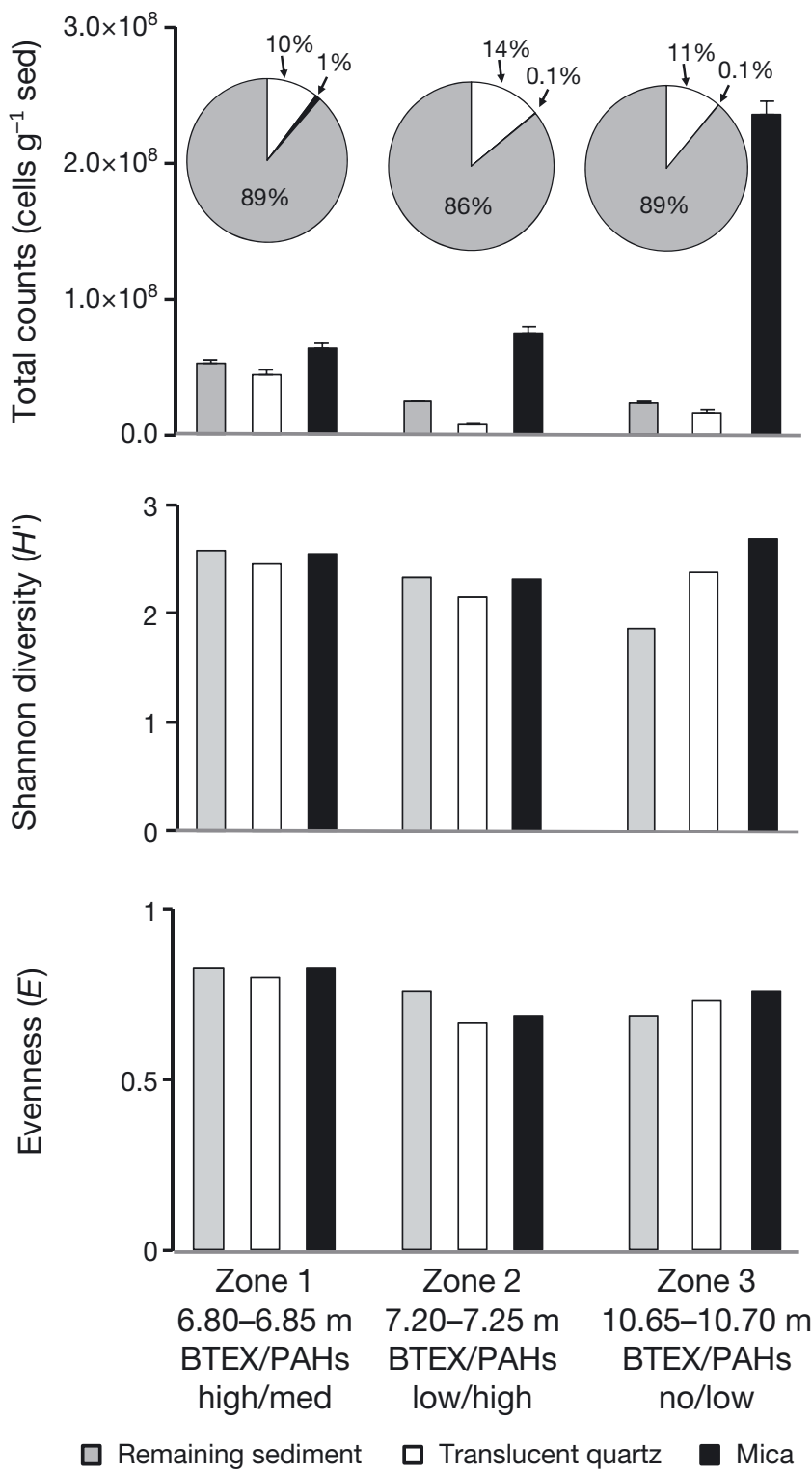

Fig. 2. Total cell counts, Shannon diversity $\left(H^{\prime}\right)$, and evenness $(E)$ of bacterial communities attached to different sediment (sed) mineral fractions from 3 zones of varying contamination in a sandy aquifer contaminated with petroleum hydrocarbons. Pie charts refer to the relative abundance of the sediment mineral fractions. BTEX: benzene, toluene, ethylbenzene, and xylenes; PAH: polycyclic aromatic hydrocarbons 
ticles (Table 2). A small fraction of 0.1 to $1 \%$ of the sediments was constituted by dark mica particles (Table 2, Fig. 2). Only minor changes in sediment composition were observed with depth, i.e. the highest mica fraction was found in Zone 1, while Zone 2 contained a slightly higher fraction of TQ (Table 2, Fig. 2).

The SEM-EDX analysis of the quartz fraction revealed a general elemental composition (mass percentage) of $\mathrm{O}$ (63 to $69 \%$ ), $\mathrm{Si}$ (26 to $33 \%$ ), and $\mathrm{Al}$ at a mass proportion of 0.8 to $1.3 \%$ in the TQ and 1.3 to $3.3 \%$ in the coated quartz. Iron was a significant element in the fraction of coated quartz, with $7 \%$ in Zone $1,3 \%$ in Zone 2 , and trace concentrations $(0.1 \%)$ in Zone 3. The TQ fraction contained Fe only at very low concentrations. Both quartz fractions contained traces of $\mathrm{Ca}, \mathrm{K}$, and $\mathrm{Mg}$. The elemental analysis of the mica fraction revealed an elemental composition (mass percentage) of O (54 to $63 \%$ ), Si (22 to $27 \%$ ), Fe (3 to $11 \%$ ), $\mathrm{Al}(5$ to $7 \%), \mathrm{K}(0.7$ to $2.4 \%), \mathrm{Na}(0.5$ to $1.8 \%)$, Ca $(0.1$ to $1.2 \%), \mathrm{Mg}(0.5$ to $0.7 \%)$, and traces of $\mathrm{Mn}, \mathrm{P}, \mathrm{S}$, and $\mathrm{Ti}$, a composition that very much refers to biotite.

\section{Sediment total cell numbers}

For the samples immediately fixed after sediment drilling, highest cell counts were found in Zone 1 (6.9 $\times 10^{7}$ cells $\mathrm{g}^{-1}$ sediment wet wt), followed by Zone 2 (1.6 to $2.2 \times 10^{7}$ cells g ${ }^{-1}$ sediment wet wt) and Zone 3 $\left(2.1 \times 10^{6}\right.$ cells $\mathrm{g}^{-1}$ sediment wet wt) (Fig. 1). Water samples revealed a different picture, with highest counts in Zone 2, followed by Zone 1 and Zone 3 (Table 1). Sediment samples reprocessed for the present study, i.e. being influenced by the sorting procedure in PBS buffer, exhibited slightly different to significantly different values for total counts in the natural mixed fractions (Figs. $1 \& 2$ ). While the numbers of attached cells agreed fairly well for samples of Zones 1 and 2, total counts in the reprocessed mixed sediment samples from Zone 3 revealed 10-fold higher cell numbers than determined in the parent samples. With regard to the individual mineral fractions, highest cell counts were always obtained for mica, independently of depth and degree of contamination (Fig. 2). The lowest cell numbers were always found with the TQ fraction (Fig. 2). A Mann-Whitney $U$-test revealed that in Zone 1 , there was no significant difference between the cell abundance on TQ and the mixed sediment fraction (mainly coated quartz) $\left(\mathrm{p}=0.85, \mathrm{n}_{1}=\mathrm{n}_{2}=3\right)$, while all other pairwise comparisons between individual sediment/mineral fractions were different by trend from each other $(\mathrm{p}=$
Table 3. Relative abundance of cells with different sediment mineral fractions

\begin{tabular}{|lcccc|}
\hline $\begin{array}{c}\text { Zone } \\
\text { Depth } \\
(\mathrm{m})\end{array}$ & $\begin{array}{c}\text { Translucent } \\
\text { quartz (\%) }\end{array}$ & $\begin{array}{c}\text { Mica } \\
(\%)\end{array}$ & $\begin{array}{c}\text { Remaining } \\
\text { sediment }(\%)^{\mathrm{a}}\end{array}$ \\
\hline 1 & $6.80-6.85$ & 19.2 & 2.7 & 78.1 \\
2 & $7.20-7.25$ & 7.4 & 0.5 & 92.1 \\
3 & $10.65-10.70$ & 9.5 & 1.2 & 89.3 \\
a Cell numbers and relative abundance of cells calculated \\
based on direct counts with translucent quartz, mica, \\
and natural mixed sediment samples
\end{tabular}

$0.01, \mathrm{n}_{1}=\mathrm{n}_{2}=3$ ). The mica fraction of Zone 3 contained more than 7 times the cells counted in other fractions (Fig. 2). However, because of the low overall content of mica in the natural sediments, the generally higher cell numbers with the mica fraction represented only a small portion of the total cells in the natural sediments (Table 3 ).

\section{Bacterial community patterns}

Both bacterial Shannon diversity and evenness were slightly higher in Zone 1 than in Zones 2 and 3, the only exception being the diversity of the mica in Zone 3 (Fig. 2). In both Zone 1 (which contained a high amount BTEX and naphthalene) and Zone 2 (which contained a high amount of adsorbed PAHs), the diversity was quite similar on all 3 mineral fractions analyzed; however, in Zone 3, where hardly any contaminants were found, the highest diversity could be found on the mica fraction, while the community on the TQ showed a lower overall diversity (Fig. 2). Likewise, Zone 1 revealed a roughly equal evenness with all 3 mineral fractions, whereas Zone 2 revealed the highest evenness on the remaining sediment fraction, and Zone 3 revealed a slightly higher evenness for the mica fraction (Fig. 2).

Although few differences were observed with regard to the bacterial diversity, the bacterial community composition, as analyzed by DNA fingerprinting, revealed significant differences between the sediments from the 3 investigated zones (Fig. 3). In total, 113 distinct T-RFs were obtained, with 14 appearing exclusively in Zone 1, 48 exclusively in Zone 2, and 30 solely in Zone 3 . Only $7 \%$ of all operational taxonomic units (OTUs) were commonly present in the 3 zones. The share of OTUs between individual zones was small, ranging from 3 to $5 \%$ (Fig. S2 in the Supplement at www.int-res.com/ articles/suppl/a076p243_supp.pdf). Looking in more 


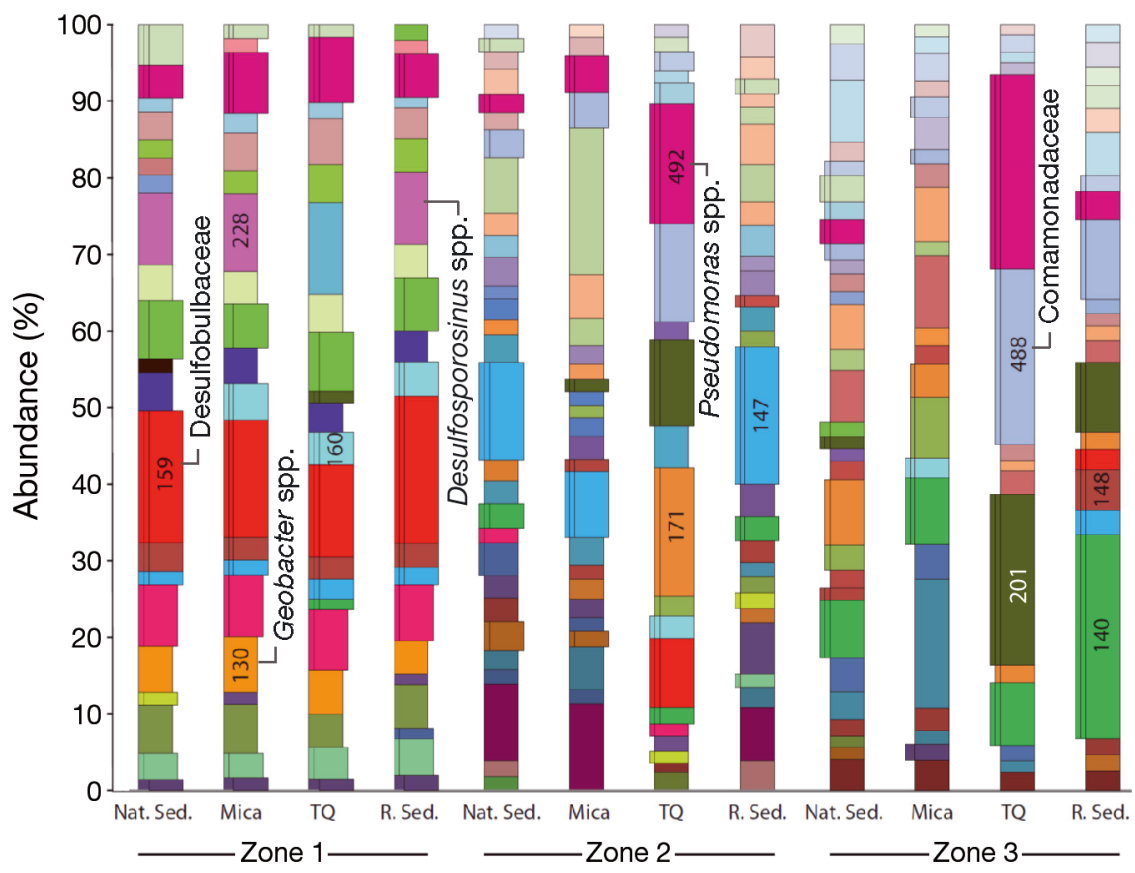

Fig. 3. Relative abundance of dominant operational taxonomic units found with the different sediment mineral fractions from 3 zones of varying contamination in a sandy aquifer contaminated with petroleum hydrocarbons. Values highlighted in individual pillars refer to specific terminal restriction fragments. Nat. Sed.: natural mixed sediment; TQ: translucent quartz; R. Sed.: remaining sediment

detail into the composition of the bacterial communities with respect to the selected mineral fractions exhibited very distinct patterns for the 3 zones. While in Zone 1 the selected mineral fractions, i.e. TQ, mica, and remaining sediment (coated quartz plus silt and clay), shared $55 \%$ of all OTUs, only $18 \%$ of OTUs were common in Zone 3, and no OTUs were commonly present in Zone 2 (Fig. S3 in the Supplement at www.int-res.com/articles/suppl/a076p243 _supp.pdf). In Zone 2, the TQ fraction hardly shared any community members with the other mineral frac-

Fig. 4. Correspondence analysis (CA) plot evaluating sediment bacterial fingerprinting data together with sediment and mineral properties as well as the physical-chemical characteristics of groundwater. Open symbols refer to the translucent quartz fraction, and black symbols refer to the mica fraction. Small dots represent specific operational taxonomic units, with numbers referring to the respective terminal restriction fragment length in base pairs. BTEX: sum of benzene, toluene, ethylbenzene, and xylenes; $\mathrm{PAH}$ : polycyclic aromatic hydrocarbons (in water [W] or on sediment $[\mathrm{S}]) ; \mathrm{S}^{2-}$ : dissolved hydrogen sulfide; DOC: dissolved organic carbon; $\mathrm{E}_{\mathrm{H}}$ : redox potential; $\mathrm{SO}_{4}{ }^{2-}$ : dissolved sulfate; Bac: total prokaryotic cell counts (in water [W] or on sediment [S]); EC: electric conductivity; Fe(II): ferrous iron dissolved in groundwater; all other letters stand for chemical elements identified during mineral analysis tions. However, as can be seen from the correspondence analysis, the TQ community was quite similar to the TQ and mica fractions in Zone 3 (Fig. 4; see below).

The most dominant OTUs were represented by the T-RFs 130, 140, 147 , 148, 159, 160, 171, 201, 228, 488, and 492 bp (Fig. 3). The T-RFs 130, 159 (possibly together with 160), and 228 bp are related to known key degraders in the contaminated aquifer, i.e. bacteria affiliated to Geobacter spp., Desulfobulbaceae (e.g. Desulfocapsa spp.), and clostridial sulphate reducers (Desulfosporosinus spp.), respectively. The T-RFs 130 and 228 were found exclusively restricted to Zone 1. T-RF 159 (and together with 160) exhibited its highest relative abundance in Zone 1 but has been found abundant in the bacterial community on TQ in Zone 2 as well (Fig. 3). T-RF 492 bp, affiliated to Pseudomonas spp., was found in all 3 different zones of the aquifer but did not show up in the mica fraction in Zone 3. T-RF $488 \mathrm{bp}$, affiliated to members of the Comamonadaceae, was present only in Zones 2 and 3, most prominently on the TQ fraction (Fig. 3). T-RF 147 was mainly found in Zone 2, and TRFs 140, 201, and 492 were dominant in Zone 3 (Fig. 4). More detailed information on the affiliation of T-RFs to specific bacterial lineages is provided in Pilloni et al. (2012) and Larentis et al. (2013).






\section{Selective drivers of sediment bacterial community patterns}

To compare the similarity between the bacterial communities in the sediment fractions TQ and mica of the 3 zones and to evaluate major drivers of bacterial community composition with regard to physicochemical conditions, contaminant chemistry, and mineral composition, individual multivariate analyses were performed. A PCA revealed a separation of the different TQ and mica fractions from the individual zones (depths) governed mainly by the contaminant loading, total amount of DOC, dissolved hydrogen sulfide, and alkalinity (vertical axis in the PCA plot; Fig. S4 in the Supplement at www.int-res.com/ articles/suppl/a076p243_supp.pdf). The 2 mineral fractions separated from each other (horizontal direction in the PCA plot) by their different mineral composition and surface roughness. A subsequent correspondence analysis revealed attached bacterial communities from TQ and mica closely clustering together in Zone 1 with respect to bacterial community composition (Fig. 4). Key environmental factors associated were again the concentrations of dissolved contaminants (BTEX and PAHs) as well as sulfide, total DOC, and alkalinity (Fig. 4). Samples from Zones 2 and 3 were clearly distant to the samples from Zone 1. Highest dissimilarity within communities between the 2 selected sediment fractions TQ and mica were observed with Zone 2, with the high concentration of adsorbed PAHs being the major driver, as indicated by the correspondence analysis.

\section{DISCUSSION}

A multitude of factors may contribute to the selective assembly of microbial communities on sediment surfaces including physical-chemical factors, sediment properties, resource availability, hydrodynamics, and the local and regional pool of diversity (Griebler \& Lueders 2009, Augspurger et al. 2010, Lindström \& Langenheder 2012, Stegen et al. 2012). Organic contaminants, such as petroleum hydrocarbons, are a carbon and energy source to a subset of the natural microbial community while being toxic to others. Moreover, a high load of organics switches aquifers from oxidized to reduced conditions. As such, petroleum hydrocarbons are considered key drivers of microbial community composition and dynamics (Vecht et al. 1988, del Castillo \& Ramos 2007, Bombach et al. 2010, Meckenstock \& Mouttaki 2011, Meckenstock et al. 2015). Groundwater ecosys- tems, in particular, are generally considered low-productivity systems characterized by comparably stable environmental conditions. As such, organic contamination may constitute an ecosystem disturbance with more pronounced effects to the intrinsic communities than in other more productive and dynamic habitats (Griebler \& Lueders 2009). In our study, we specifically investigated the influence of organic contamination, i.e. BTEX and PAHs, and water chemistry in comparison to individual sediment properties, such as mineral composition and surface roughness, onto the composition and cell density of attached microbial communities in a shallow sandy aquifer. Our working hypothesis assumed that sediment properties are indeed active selective factors shaping sediment microbial community patterns but are superimposed by organic contaminants at high loadings.

The shallow sandy aquifer at the former gasworks site in Düsseldorf-Flingern, Germany, was heavily contaminated locally by subsurface disposal of tar oil several decades ago (Anneser et al. 2008). Still, petroleum hydrocarbons, i.e. mainly monoaromatic (BTEX) and PAHs, partition from the contaminant source into groundwater and form a contaminant plume (Anneser et al. 2008, Prommer et al. 2009, Meckenstock et al. 2010). With respect to the contamination, we distinguished 3 zones in the vertical direction within the shallow aquifer, a zone of highly contaminated groundwater (Zone 1), a zone with high concentrations of contaminants adsorbed to the sediment matrix (Zone 2), and a zone with only minor contamination (Zone 3) (Fig. 1). Microbial community composition investigated in natural (mixed) aquifer sediments collected from different zones and depths of the respective aquifer has been studied in earlier work with respect to key contaminant degraders (Winderl et al. 2008, Pilloni et al. 2011, 2012, Larentis et al. 2013), redox gradients (Anneser et al. 2008, 2010), and sulfur cycling (Einsiedl et al. 2015). Here, we specifically evaluate individual selective forces responsible for shaping sediment microbial community composition and biomass including organic contamination and water chemistry. Moreover, two very different mineral fractions, i.e. TQ and mica, were selected and sorted from the natural sediments to test for the influence of sediment properties.

It was striking that the attached bacterial communities from the different depths of the contaminated aquifer face very different environmental conditions that actively shape the composition of the attached bacterial communities. Only $7 \%$ of all OTUs were found in common with the different zones. This core microbiome consisting of 8 T-RFs $(140,147,148,159$, 
160, 201, 492, 509) displayed opposing abundances. T-RF 159 was most abundant in Zone 1, whereas TRF 147 was mainly found in Zone 2, and T-RFs 140, 201, and 492 were dominant in Zone 3 (Figs. 3 \& 4). In Zone 1, exhibiting high concentrations of petroleum hydrocarbons (BTEX and PAHs) and dissolved hydrogen sulfide in groundwater as well as a considerable concentration of PAHs adsorbed to the sediment matrix, the organic contamination superimposed all other factors potentially contributing to the assembly of sediment bacterial communities. The share of $58 \%$ of OTUs between the TQ and the mica fraction accounted for the highest similarity in community composition when compared to the other zones (Fig. S3 in the Supplement). Moreover, bacterial Shannon diversity and evenness were not significantly different, and the 2 different minerals carried a similar number of attached cells per gram sediment. This changed completely in Zone 2, where, with a share of only $3 \%$ of OTUs, the 2 mineral fractions were characterized by 2 completely different bacterial communities. The mica community especially separated from all others, mainly driven by the high concentration of PAHs adsorbed to the sediment. This selectivity was reflected by the high number of OTUs $(42 \%)$ that were found exclusively in Zone 2. Here, it needs to be considered that petroleum hydrocarbons show a lower sorption to quartz than to mica (Kleineidam et al. 1999a,b, Müller et al. 2007). Additionally, already at a low sediment organic carbon (OC) content, PAHs effectively sorb to surfaces, with mica, the iron-coated quartz, and silt and clay significantly exceeding the OC content of TQ (Müller et al. 2007, Anneser et al. 2010). It thus can be assumed that the PAH loading was much higher on mica and the remaining sediment fraction (sediment that was depleted in TQ and mica) than on the TQ. And, indeed, between the mica fraction and the remaining sediment fraction, a significantly higher share of OTUs $(27 \%)$ was found. These facts clearly point to adsorbed PAHs being the main driver for bacterial community composition in Zone 2. Opposite to what was expected for Zone 3, with its minor contamination, the pronounced differences in attached bacterial community composition, with a share of only $26 \%$ of OTUs, could not be explained by sediment properties. In fact, mineral composition and surface roughness only had a low and non-significant explanatory power in the correspondence analysis using the post hoc analysis envfit. While the correspondence analysis shows the high similarity of the samples in Zone 1, sharing several key taxa, which can be explained by the high levels of contam- ination, it also indicates that bacterial communities on mica were highly different in the 3 zones. In comparison, the OTUs found on TQ did not separate as much in the ordination plot. TQ samples from Zones 2 and 3 differed only marginally. This clearly indicates distinct drivers that influence the community composition on mica and TQ.

Within each of the 3 zones tested, the total numbers of attached cells were always highest on the mica fractions and lowest on the TQ, indicating that surface roughness and thus specific surface area do play a role in microbial colonization of sediments. This difference in cell numbers with TQ and mica was small, although of borderline significance, in Zones 1 and 2, with their high contamination, but well pronounced in Zone 3 (Fig. 2). A positive relationship between bacterial cell numbers and sediment surface area has been observed in many other studies (Meadows \& Anderson 1968, Dale 1974, Nickels et al. 1981, DeFlaun \& Mayer 1983).

The important role of contamination as a strong selective force is also obvious from the bacterial community composition in terms of specific OTUs detected. In Zone 1, known key degraders of BTEX, i.e. representatives of the taxa of Geobacter spp. (TRF $130 \mathrm{bp}$ ), Desulfobulbaceae (T-RF $159 \mathrm{bp}$ ), and Desulfosporosinus spp. (T-RF $228 \mathrm{bp}$ ), that have been identified in previous studies at this site (Winderl et al. 2008, Anneser et al. 2010, Pilloni et al. 2011, 2012, Larentis et al. 2013) were most abundant. Moreover, their relative abundance did not differ significantly between TQ and mica (Fig. 3). Specific BTEX degraders (T-RFs 130 and 228) were not detected in Zones 2 and 3. The BTEX thus contribute to the assembly of bacterial communities, being a priority OC and energy source. However, the fact that other OTUs, abundant in Zones 2 and 3, are absent in Zone 1, e.g. T-RF 488, may also point at BTEX being a toxicant to many microbes (Sikkema et al. 1995, Isken \& de Bont 1998). A similar conclusion is drawn by Rizoulis et al. (2013), who studied microbial communities in a phenol-contaminated sandstone aquifer.

In conclusion, our study underlines the overwhelming role of aromatic petroleum hydrocarbons, which are prominent pollutants in groundwater ecosystems, in shaping sediment bacterial communities. Organic contamination with the very mobile BTEX, as present in Zone 1, was shown to superimpose the selective power of sediment properties such as mineral composition and surface roughness that were frequently shown to significantly influence colonization, establishment, and composition of attached microbial communities. However, with the more immobile and 
adsorbed PAHs, contaminating Zone 2, sediment properties came indirectly into play because surface roughness and sediment coating are linked to OC content, which itself is linked to sorption capacity. There is a strong indication that PAHs mainly adsorbed to sediment fractions other than the TQ are responsible for the tremendous differences in sediment community composition found in Zone 2 . The most pronounced direct influence of sediment properties on attached bacterial community composition was revealed in Zone 3, where the organic contamination was minor.

This study has provided a better understanding of factors driving the assembly of sessile microbial communities in a tar oil contaminated porous sandy aquifer, revealing pronounced phylogenetic differences within sediment bacterial communities with respect to mineralogy and contaminant load. Without doubt, only a small selection of environmental parameters have been tested, while others, such as biological factors, i.e. top-down control on bacterial communities via protozoan grazing and viral lysis (Šimek et al. 2003, Kent et al. 2007, Salcher et al. 2005, Wey et al. 2008), await evaluation. Also, the temporal dynamics of sediment bacterial communities caused by the continuous exchange of cells between the water and sediment phase need to be tested (Zhou et al. 2012, Hug et al. 2015). Another point of interest refers to ecological theory with respect to microbial community assembly at a local and regional scale (Lindström \& Langenheder 2012). A highly contaminated zone within an aquifer characterized by highly specific microbial communities, as introduced in the present study, constitutes a continuous source of species and specific functions to downgradient environmental compartments including surface waters and soils (Hug et al. 2015).

Acknowledgements. This study was funded by the German Research Foundation (DFG) as part of the research group Reactions in Porous Media (FOR 525; subprojects GR 2107/1-2 and Gr 2107/3-1) and the grant Ci-26/9-1. Thanks go to Tillmann Lüders and Kathrin Hörmann from the Institute of Groundwater Ecology for help with molecular community analysis. We thank Marc Schwientek and Hermann Rügner from the Center of Applied Geosciences at the University of Tübingen, Germany, for valuable comments on PAH sorption to sediments and minerals.

\section{LITERATURE CITED}

Alfreider A, Krössbacher M, Psenner R (1997) Groundwater samples do not reflect bacterial densities and activity in subsurface systems. Water Res 31:832-840
Anneser B, Einsiedl F, Meckenstock RU, Richters L, Wisotzky F, Griebler C (2008) High-resolution monitoring of biogeochemical gradients in a tar oil-contaminated aquifer. Appl Geochem 23:1715-1730

> Anneser B, Pilloni G, Bayer A, Lueders T, Griebler C, Einsiedl F, Richters L (2010) High resolution analysis of contaminated aquifer sediments and groundwater-What can be learned in terms of natural attenuation? Geomicrobiol J 27:130-142

> Augspurger C, Karwautz C, Mussmann M, Daims H, Battin TJ (2010) Drivers of bacterial colonization patterns in stream biofilms. FEMS Microbiol Ecol 72:47-57

Bakker DP, Klijnstra JW, Busscher HJ, van der Mei HC (2003) The effect of dissolved organic carbon on bacterial adhesion to conditioning films adsorbed on glass from natural seawater collected during different seasons. Biofouling 19:391-397

Banfield JF, Hamers RJ (1997) Processes at minerals and surfaces with relevance to microorganisms and prebiotic synthesis. Rev Mineral 35:81-122

Bayer A, Drexel R, Weber N, Griebler C (2016) Quantification of aquatic sediment prokaryotes - A multi-steps optimization testing sands from pristine and contaminated aquifers. Limnologica 56:6-13

> Bennett PC, Hiebert FK, Rogers JR (2000) Microbial control of mineral-groundwater equilibria: macroscale to microscale. Hydrogeol J 8:47-62

Bennett PC, Rogers JR, Choi WJ, Hiebert FK (2001) Silicates, silicate weathering, and microbial ecology. Geomicrobiol J 18:3-19

Bombach P, Chatzinotas A, Neu TR, Kästner M, Lueders T, Vogt C (2010) Enrichment and characterization of a sulfate-reducing toluene-degrading microbial consortium by combining in situ microcosms and stable isotope probing techniques. FEMS Microbiol Ecol 71: 237-246

Boyd ES, Cummings DE, Geesey GG (2007) Mineralogy influences structure and diversity of bacterial communities associated with geological substrata in a pristine aquifer. Microb Ecol 54:170-182

Carson JK, Campbell L, Rooney D, Clipson N, Gleeson DB (2009) Minerals in soil select distinct bacterial communities in their microhabitats. FEMS Microbiol Ecol 67: 381-388

> Dale NG (1974) Bacteria in intertidal sediments: factors related to their distribution. Limnol Oceanogr 19: 509-518

> DeFlaun MF, Mayer LM (1983) Relationship between bacteria and grain surfaces in intertidal sediments. Limnol Oceanogr 28:873-881

$>$ del Castillo T, Ramos JL (2007) Simultaneous catabolite repression between glucose and toluene metabolism in Pseudomonas putida is channeled through different signaling pathways. J Bacteriol 189:6602-6610

Dubois IE, Holgersson S, Allard S, Malmström ME (2010) Correlation between particle size and surface area for chlorite and K-feldspar. Water-Rock Interaction 13: 717-720

Edwards KJ, Rutenberg AD (2001) Microbial response to surface microtopography: the role of metabolism in localized mineral dissolution. Chem Geol 180:19-32

Einsiedl F, Pilloni G, Ruth-Anneser B, Lueders T, Griebler C (2015) Spatial distribution of sulfur species and sulphatereducing bacteria provide insights into sulfur redox cycling and biodegradation hot-spots in a hydrocarbon- 
contaminated aquifer. Geochim Cosmochim Acta 156: 207-221

Fazi S, Amalfitano S, Piccini C, Zoppini A, Puddu A, Pernthaler J (2008) Colonization of overlaying water by bacteria from dry river sediments. Environ Microbiol 10: 2760-2772

Flynn TM, Sanford RA, Bethke CM (2008) Attached and suspended microbial communities in a pristine confined aquifer. Water Resour Res 44:W07425

> Flynn TM, Sanford RA, Ryu H, Bethke CM, Levine AD, Ashbolt NJ, Domingo JWS (2013) Functional microbial diversity explains groundwater chemistry in a pristine aquifer. BMC Microbiol 13:146

Foght J (2008) Anaerobic biodegradation of aromatic hydrocarbons: pathways and prospects. J Mol Microbiol Biotechnol 15:93-120

> Gadd GM (2010) Metals, minerals and microbes: geomicrobiology and bioremediation. Microbiology 156:609-643

Geesey GG (2001) Bacterial behavior at surfaces. Curr Opin Microbiol 4:296-300

Griebler C, Lueders T (2009) Microbial biodiversity in groundwater ecosystems. Freshw Biol 54:649-677

> Griebler C, Mindl B, Slezak D, Geiger-Kaiser M (2002) Distribution patterns of attached and suspended bacteria in pristine and contaminated shallow aquifers studied with an in situ sediment exposure microcosm. Aquat Microb Ecol 28:117-129

> Heider J (2007) Adding handles to unhandy substrates: anaerobic hydrocarbon activation mechanisms. Curr Opin Chem Biol 11:188-194

Hirsch P (1992) Observations on the physiology of microorganisms from pristine ground water environments. In: Matthess G, Frimmel F, Hirsch P, Schulz HD, Usdowski HE (eds) Progress in hydrogeochemistry. SpringerVerlag, Berlin, p 344-347

Hirsch P, Rades-Rohkohl E, Kölbel-Boelke J, Nehrkorn A (1992) Morphological and taxonomic diversity of ground water microorganisms. In: Matthess G, Frimmel F, Hirsch P, Schulz HD, Usdowski HE (eds) Progress in hydrogeochemistry. Springer-Verlag, Berlin, p 311-325

> Hug LA, Thomas BC, Brown CT, Frischkorn KR, Williams KH, Tringe SG, Banfield JF (2015) Aquifer environment selects for microbial species cohorts in sediment and groundwater. ISME J 9:1846-1856

Isken S, de Bont JAM (1998) Bacteria tolerant to organic solvents. Extremophiles 2:229-238

Kanzog C, Ramette A (2009) Microbial colonisation of artificial and deep-sea sediments in the Arctic Ocean. Mar Ecol 30:391-404

Kent AD, Yannarell AC, Rusak JA, Triplett EW, McMahon KD (2007) Synchrony in aquatic microbial community dynamics. ISME J 1:38-47

Kleineidam S, Rügner H, Grathwohl P (1999a) Influence of petrographic composition/organic matter distribution of fluvial aquifer sediments on the sorption of hydrophobic contaminants. Sediment Geol 129:311-325

Kleineidam S, Rügner H, Ligouis B, Grathwohl P (1999b) Organic matter facies and equilibrium sorption of phenanthrene. Environ Sci Technol 33:1637-1644

Kölbel-Boelke J, Hirsch P (1989) Comparative physiology of biofilm and suspended organisms in the groundwater environment. In: Characklis WG, Wilderer PA (eds) Structure and function of biofilms. John Wiley \& Sons, New York, NY, p 221-238

Köster M, Dahlke S, Meyer-Reil LA (2005) Microbial colo- nization and activity in relation to organic carbon in sediments of hypertrophic coastal waters (Nordrügensche Bodden, Southern Baltic Sea). Aquat Microb Ecol 39: 69-83

> Larentis M, Hörmann K, Lueders T (2013) Fine-scale degrader community profiling over an aerobic/anaerobic redox gradient in a toluene-contaminated aquifer. Environ Microbiol Rep 5:225-234

> Lindström ES, Langenheder S (2012) Local and regional factors influencing bacterial community assembly. Environ Microbiol Rep 4:1-9

> Llobet-Brossa E, Rossello-Mora R, Amann R (1998) Microbial community composition of Wadden Sea sediments as revealed by fluorescence in situ hybridization. Appl Environ Microbiol 64:2691-2696

Ludwig W, Strunk O, Westram R, Richter L and others (2004) ARB: a software environment for sequence data. Nucleic Acids Res 32:1363-1371

Mauck BS, Roberts JA (2007) Mineralogic control on abundance and diversity of surface-adherent microbial communities. Geomicrobiol J 24:167-177

- Meadows PS, Anderson JG (1968) Micro-organisms attached to marine sand grains. J Mar Biol Assoc UK 48: 161-175

> Meckenstock RU, Mouttaki H (2011) Anaerobic degradation of non-substituted aromatic hydrocarbons. Curr Opin Biotechnol 22:406-414

Meckenstock RU, Lueders T, Griebler C, Selesi D (2010) Microbial hydrocarbon degradation at coal gasification plants. Handbook of hydrocarbon and lipid microbiology. Springer-Verlag, Berlin, p 2293-2312

Meckenstock RU, Elsner M, Griebler C, Lueders T and others (2015) Biodegradation: updating the concepts of control for microbial clean-up in contaminated aquifers. Environ Sci Technol 49:7073-7081

Müller S, Totsche KU, Kögel-Knabner I (2007) Sorption of polycyclic aromatic hydrocarbons to mineral surfaces. Eur J Soil Sci 58:918-931

Nickels JS, Bobbie RJ, Martz RF, Smith GA, White DC, Richards NL (1981) Effect of silicate grain shape, structure and location on the biomass and community structure of colonizing marine microbiota. Appl Environ Microbiol 41:1262-1268

Oksanen J, Blanchet FG, Kindt R, Legendre P and others (2013) vegan: community ecology package. Available at http://cran.r-project.org/web/packages/vegan/index. html

Pilloni G, von Netzer F, Engel M, Lueders T (2011) Electron acceptor-dependent identification of key anaerobic toluene degraders at tar-oil-contaminated aquifer by Pyro-SIP. FEMS Microb Ecol 78:165-175

Pilloni G, Granitsiotis MS, Engel M, Lueders T (2012) Testing the limits of 454 pyrotag sequencing: reproducibility, quantitative assessment and comparison to T-RFLP fingerprinting of aquifer microbes. PLoS ONE 7:e40467

> Prommer H, Anneser B, Rolle M, Einsiedl F, Griebler C (2009) Biogeochemical and isotopic gradients in a BTEX/ PAH contaminant plume: model-based interpretation of a high-resolution field data set. Environ Sci Technol 43: 8206-8212

> Reardon CL, Cummings DE, Petzke LM, Kinsall BL, Watson DB, Peyton BM, Geesey GG (2004) Composition and diversity of microbial communities recovered from surrogate minerals incubated in an acidic uranium-contaminated aquifer. Appl Environ Microbiol 70:6037-6046 
Rizoulis A, Elliott DR, Rolfe SA, Thornton SF, Banwart SA, Pickup RW, Scholes JD (2013) Diversity of planktonic and attached bacterial communities in a phenol-contaminated sandstone aquifer. Microb Ecol 66:84-95

Rogers JR, Bennett PC (2004) Mineral stimulation of subsurface microorganisms: release of limiting nutrients from silicates. Chem Geol 203:91-108

Salcher MM, Pernthaler J, Psenner R, Posch T (2005) Succession of bacterial grazing defense mechanisms against protistan predators in an experimental microbial community. Aquat Microb Ecol 38:215-229

Sikkema J, de Bont JA, Poolman B (1995) Mechanisms of membrane toxicity of hydrocarbons. Microbiol Rev 59: 201-222

Šimek K, Horňák K, Mašín M, Christaki U, Nedoma J, Weinbauer MG, Dolan JR (2003) Comparing the effects of resource enrichment and grazing on a bacterioplankton community of a meso-eutrophic reservoir. Aquat Microb Ecol 31:123-135

Stegen JC, Lin X, Konopka AE, Fredrickson JK (2012) Stochastic and deterministic assembly processes in subsurface microbial communities. ISME J 6:1653-1664

Editorial responsibility: Karel Šimek, České Budějovice, Czech Republic
Suarez DL, Wood JD (1998) Long term weathering rates of twelve mineral fractions isolated from a granodiorite derived soil. Mineral Mag 62A:1473-1474

> Vecht SE, Platt MW, Er-El Z, Goldberg I (1988) The growth of Pseudomonas putida on m-toluic acid and on toluene in batch and in chemostat cultures. Appl Microbiol Biotechnol 27:587-592

Watnick P, Kolter R (2000) Biofilm, city of microbes. J Bacteriol 182:2675-2679

> Wey JK, Scherwass A, Norf H, Arndt H, Weitere M (2008) Effects of protozoan grazing within river biofilms under semi-natural conditions. Aquat Microb Ecol 52: 283-296

Winderl C, Anneser B, Griebler C, Meckenstock RU, Lueders T (2008) Depth-resolved quantification of anaerobic toluene degraders and aquifer microbial community patterns in distinct redox zones of a tar oil contaminant plume. Appl Environ Microbiol 74:792-801

Zhou Y, Kellermann C, Griebler C (2012) Spatio-temporal patterns of microbial communities in a hydrologically dynamic pristine aquifer. FEMS Microbiol Ecol 81: 230-242

Submitted: August 17, 2015; Accepted: December 9, 2015 Proofs received from author(s): February 9, 2016 